The International Journal of Engineering and Science (IJES)

|| Volume || 6 || Issue || 6 || Pages || PP 01-08 || 2017 ||

ISSN (e): $2319-1813 \operatorname{ISSN}(\mathrm{p}): 2319-1805$

\title{
Industrial Installation Skills Acquired and Job Performance of Graduates of Electrical Installation and Maintenance Works Trade of Technical Colleges in North Eastern Nigeria
}

\author{
Dauda Moses ${ }^{1}$, Daniel Kaleb Diraso ${ }^{2}$, Paul ShehuYaduma ${ }^{3}$, Danlami Agbu ${ }^{4}$ \\ ${ }^{I}$ Department of Electrical Technology Education, ModibboAdama University of Technology, Yola, Adamawa \\ State, Nigeria \\ ${ }^{2}$ Department of Technology Education, ModibboAdama University of Technology, Yola, Adamawa State, \\ Nigeria \\ ${ }^{3}$ Department of Vocational and Technology Education, AbubakarTafawaBalewa University, Bauchi, Bauchi \\ State, Nigeria \\ ${ }^{4}$ Department of Electrical Engineering, Taraba State Polytechnic Suntai, Jalingo, Taraba State, Nigeria
}

\begin{abstract}
.
This study was conducted to determine level of skills acquired and job performance of graduates of electrical installation and maintenance work (EIM) trade of technical colleges in industrial installation in north eastern Nigeria with a view of finding information that will help solve low level of skill acquisition and job performance of the graduates in order to sustain the graduates' human and job security for national development. The study was guided by two research questions and one hypothesis. Descriptive survey research design based on core self-evaluation was used for the study. The population for the study consisted of 313 graduate of electrical installation and maintenance work trade and 82 work place supervisors in 33 public establishment in north eastern Nigeria. The entire population was used for the study. Two sets of structured questionnaires were used for data collection. Each of the questionnaires has 32 items in four task cluster within two major sections. The instrument was validated by three electrical technology lecturers form ModibboAdama University of Technology, Yola and three EIM teachers and workshop based supervisor each from government science and technical college and federal ministry of works and jos respectively. The entire validated instrument was tested for internal consistence using the cronbach Alpha method which yielded reliability coefficient of 0.85 . The data for the study were analyzed using the mean, mean of means and z-test statistical methods using the SPSS 17.0 for windows. Findings of the study include among others that the graduate of electrical installation and maintenance works trade of technical colleges in north eastern Nigeria moderately acquired skills in installation of MICC cables and slightly acquired skills in installation of ducks and trunking task clusters respectively of the industrial installation module. While the graduate exhibited moderate level of job performance in installation of MICC cables and low job performance in installation of ducks and trunking tasks clusters, there was no significance difference in the mean response of graduate and supervisor on level of job performance of graduate in industrial installation module as a whole. It was recommended among others that government should provide adequate training facilities at the technical colleges especially on the task clusters that the graduates were deficient in. On the job remedial training should be provided by employers to remedy the very low skills acquired by graduates of EIM in some task clusters in industrial installation Key words:Graduates, Industrial Installation, Job Performance, Skills Acquired, Supervisors,
\end{abstract}

Date of Submission: 24 March 2017

Date of Accepted: 15 June 2017

\section{INTRODUCTION}

The $21^{\text {st }}$ Century is the age of science and technology, exploration, experimentation and development where Nigeria needs to compete favourably with other nations in business and industry, in new methods and new techniques. This requires not only capital investment, but also a workforce that is knowledgeable and has the flexibility to acquire new skills for new jobs as the structures of the economy and occupations change. The search therefore, is for skilled workers and for specialist in new and growing fields such as Technical Education [1].

[2] noted that, the training in vocational and technical education enable the trainee to be skillful, self-reliant, enterprising and ready to create opportunities for business towards self and societal empowerment; because the flexibility and productivity of any workforce is critically dependent on availability of skilled workers especially technicians and artisans. [3]asserted that employers are looking for graduates who have specific skills, knowledge and ability to be productive enough to identify and solve problems. Such employers wishes to 
employ graduates that have good academic achievement and possesses both technical and soft skills such as communication skills, problem solving skills and the ability to be flexible.

[4]characterize today's working climate as the "third wave" of the industrial revolution with the first and second being steam and the assembly line, respectively. They confirm that this wave mandates students to acquire a new set of skills to survive economically, politically, and socially. Two consequential skill inventories have shed light on generic skills that employers deem necessary for success in the workplace. [5], argues that basic skills and competence are more required than communication skills. [6]maintained that the most important skills for any employee are the technical skills, reading, writing and computation.

Technical educations for workplace readiness, and the opportunities for technical education, are in dire need in the country [7]. One contributing factor is our educational system's lack of adequate instructional content (curricula, instruction and support variables). In her book entitled Teaching Workplace Skills, [8] argues that educators spend much time discussing theories, sharing knowledge, experimenting and searching for concepts, while employers who hire students who graduate from our educational system want to see results and want their employees to be able to do something with their knowledge. Specifically in occupational programs, a clear implication of employers' complaints is that an emphasis on technical or job-specific skill is inadequate [9]. [10]stated that, the quality of learning outcome demonstrated by students of a training programme will determine the extent to which behavioural objectives have been achieved. [11] affirms that vocational and technical education are having difficulty keeping pace with (technological) trends. Consequently, [12] contends that employers are having trouble transferring these new technologies into the work place, since many workers lack the knowledge and technical skills on which to build new learning experiences. In the same vein, [13] submitted that lack of financial resources, inadequate trained vocational teachers and lack of teaching resources have greatly contributed to the unpreparedness of graduates of technical colleges for the workforce and their subsequent job performance within the workplace.

Organizations need highly job performing individuals in order to meet their goals, to deliver the products and services they specialized in, and finally to achieve competitive advantage. Job performance is also important for any individual worker and whenever a worker accomplish tasks and performs at a high level, he will have satisfaction, with feelings of mastery and pride [14]. Low performance and not achieving the goals might be experienced as dissatisfying or even as a personal failure. Moreover, job performance if it is recognized by others within the organization is often rewarded by financial and other benefits. Although there might be exceptions, high performers according to[15], get promoted more easily within an organization and generally have better career opportunities than low performers. Despite the picture that attempted to capture dimensions of job performance existing across all jobs, the present decade especially in Nigeria is marked by long-range of unemployment for many middle-aged and older workers; a declining job market for youth who lacked skills or experience; more women entering or re-entering the world of work, and a flood of young job seekers attaining working age [16].

The increasing complexities of industrial development and production have created new requirements for technical personnel much more rapidly than our educational system been able to adjust to meet these needs. Consequently, the development of sound technical and vocational education (TVE) is central to the nation's desire of becoming industrialized and self-reliant. However, present realities in Nigeria indicate that it will take more than a mere refocusing of technical education in its present format to make it more relevant, responsive and effective in delivering graduates with requisite skills and training that can perform to the satisfaction of their employers [17],[18].

Okoye cited in [20] attributed the widening gap between programmes offered in technical colleges and the actual openings available in the labour market to the mismatch between skills demanded in the work place and those provided by the schools. In most key sectors of the economy, middle manpower shortages persist and the country remains over-dependent on the skills of expatriates. A clear indication that something vital is missing from the graduates of our middle schools; technical colleges inclusive [21]. In countries like Ghana, Britain, Cote d'Ivoire and Nigeria, there is a considerable gap between what is learned in the classroom and the real life context of students' present or future world of work [22]; [23]; [24]; [25]; [20].According to [26] the performance of graduates in higher skill areas is low. It was in the light of the poor performance of our craftsmen that forced the Nigerian public to question the relevance of our nation's technical colleges [27].

All the Technical Colleges in North Eastern Nigeria have been graduating craftsmen and master craftsmen in Electrical Installation and Maintenance Works. Majority of these graduates are gainfully employed in different (both public and private) organizations within the North East zone and in some parts of Nigeria [28]. Their employers therefore, have great expectations that they will perform well on the job. Little or no effort is made to look into how these graduates are performing on the job. With the review of the EIM Curriculum in 2007 and the graduation of ten sets of students that passed through the reviewed curriculum in the North Eastern states Technical Colleges, appraising the skills acquired and the level of job performance of the graduates in their workstations is pertinent and hence the justification and major thrust of this study. 


\subsection{Purpose of the Study}

The purpose of this study therefore was to determine level of skills acquired and job performance of graduates of electrical installation and maintenance works of trade of technical colleges in industrial installation in North Eastern Nigeria. Specifically, the study sought to determine:

1. The level of skills acquired in industrial installation by graduates of electrical installation and maintenance works trade of technical colleges in North Eastern Nigeria

2. The level of job performance of gradates of electrical installation and maintenance works trade of technical colleges in industrial installation

\subsection{Research Questions}

The study answered two research questions as follows:

1. What is the level of skills acquired in industrial installation by graduates of electrical installation and maintenanceworks trade of technical colleges in North Eastern Nigeria?

2. What is the level of job performance of gradates of electrical installation and maintenance works trade of technical colleges in industrial installation?

\subsection{Hypothesis}

One hypothesis was formulated to guide the study as follows

$\mathrm{HO}_{1}$ There is nosignificant difference between the mean ratings of graduates of electrical installation and maintenance works trade of technical colleges and their supervisors on the job performance of graduates in industrial installation

\section{METHODOLOGY}

The research design employed for this study was descriptive survey research design. According to [29], a descriptive survey is an assessment of present state of affairs usually carried out through questionnaires, opinions and interviews. The design was suitable for the study since it elicited information from graduates on core self-evaluation and their workplace supervisors on level of skills acquired and job performance of graduates of technical college electrical installation and maintenance works trade.

The study was conducted in Adamawa, Bauchi, Borno, Gombe, Taraba and Yobe States. The six States formed the Northeast Geopolitical zone of Nigeria and were chosen because there are adequate public industries that avails the graduates the opportunity to practice their chosen career. Moreover, choice of the area revealed relevant information concerning spread and general abilities possessed by graduates of electrical installation and maintenance works trade of technical colleges in North Eastern Nigeria. The North Eastern Nigeria lies between Latitude $6^{0} 18^{1}$ to $14^{0} 32^{1} \mathrm{~N}$ and Longitude $10^{0} 11^{1}$ to $14^{0} 35^{1} \mathrm{E}$ [30].

The population for the study was the 313 technical college electrical installation and maintenance work graduates and the 82 electrical installation and maintenance workplace-based supervisors that are working in public sectors in North Eastern Nigeria. Since the population of EIM graduates was manageable, the whole population was used for the study. Hence, there was no sampling

Two sets of structured questionnaire developed by the researchers were used for data collection. The questionnaires were developed using National Board for Technical Education [31]syllabus for technical college electrical installation and maintenance works trade and other related literatures. The questionnaires were face and content validated by three electrical technology education lecturers from ModibboAdama University of Technology, Yola. Also three EIM teachers and workshops based supervisors each from Government Science and Technical College and Federal Ministry of Works Jos, Plateau State, Nigeria respectively, were used in the validation of the instrument. The researchers with the help of two research assistants administered the instrument through a trial test to 20 graduates of technical college electrical installation and maintenance works trade, and 10 workshop-based supervisors in Plateau State ministries of works and rural development. The instrument was administered once on the respondents and the Crouchback alpha reliability formula was used to determine the coefficient of reliability ( $r$ ) of the instrument. The choice of the formula was necessary to determine the internal consistency of the items within the instrument. The reliability coefficient of the instrument was 0.85 . The first set of the questionnaire titled "Electrical Installation and Maintenance Works Graduates' Skill Acquired Questionnaire (EIMWGSAQ)" was administered on the graduates to rate level of skills they acquired" The second set of questionnaire titled "Electrical Installation and Maintenance Works Graduates' Performance Questionnaire (EIMWGJPQ)" was administered on both the graduates and their workplace supervisors to rate level of job performance of the graduates. The second set of the instrument which had similar structure and description except in the response pattern was administered on the graduates and their workplace supervisors. Mean, mean of means and z-test statistics were used to analyze data obtained for the study. Mean and mean of means were used to answer the two research questions while the z-test inferential statistic was used to test the null hypothesis at 0.05 level of significance. 


\section{RESULTS}

Results obtained were presented based on the research questions and hypothesis that guided the study. Results presented were also based on the five task clusters as contain in industrial installation module of the electrical installation and maintenance works trade. To answer research question one, mean ratings of graduates on the level of skills acquired in industrial installation module were calculated, and presented in TABLE 1.

Table 1: Mean Ratings of Graduates of EIM on Level of Skills Acquired In Industrial Installation

\begin{tabular}{|c|c|c|c|c|}
\hline \multirow[t]{2}{*}{ S/N } & \multirow[t]{2}{*}{ Industrial Installation Module (CEI 12) } & \multirow[b]{2}{*}{$\overline{\mathrm{x}}$} & \multirow[b]{2}{*}{5} & \multirow[b]{2}{*}{ Remarles } \\
\hline & & & & \\
\hline & Cluster 1: Installation of MICC Cables & & & \\
\hline 1 & Identification of MICC cables & 450 & 122 & EA \\
\hline 2 & Correct selection of tools/materials used in MICC cable installation & 4.57 & 1.10 & EA \\
\hline 3 & Carry out MICC cable installations observing relevant regulations & 138 & 0.96 & $\mathrm{NA}$ \\
\hline 4 & Termination of MCC cables emphasizing IEEE regulations & 1.16 & 0.54 & NA \\
\hline \multirow[t]{2}{*}{5} & Conducting various tests on completed MICC installations applying & & & \\
\hline & statutory regulations & 1.16 & 0.58 & NA \\
\hline 6 & Ability to carry-out simple surface wiring for industrial installations & 3.02 & 1.14 & MLA \\
\hline 7 & Ability to carry-out simple conduit wiring for industrial installations & 5321 & 1.47 & MLA \\
\hline \multirow[t]{3}{*}{8} & Installation of MICC cables applying necessary safety measures & 390 & 1.17 & HA \\
\hline & & 2.36 & 1.03 & MA \\
\hline & Cluster 2: Installation of Ducts and Trunling & & & \\
\hline 9 & Ability to differentiate types of ducts/trunking & 136 & 0.78 & NA \\
\hline 10 & Ability to join different lengths of ducts/trunking & 121 & 0.45 & NA \\
\hline 11 & Accurate marking out when cutting holes & 128 & 1.01 & NA \\
\hline 12 & Making bend/set/shape/file & 1.15 & 1.05 & $\mathrm{NA}$ \\
\hline 13 & Ability to fabricate accessories used for ducts/trunking & 1.10 & 0.98 & $\mathrm{NA}$ \\
\hline 14 & Ability to provide earth continuity in all types of ducts / trunking & 137 & 0.85 & NA \\
\hline \multirow[t]{2}{*}{15} & Observation of safety measures as provided by IEEE regulations & 3.50 & 152 & HA \\
\hline & Cluster 3: Installation of AC and DC Machines & & & \\
\hline 16 & Identification of various types of electrical machines & 4.76 & 2.00 & EA \\
\hline 17 & Ability to identify various types of machine enclosures & 4.50 & 1.02 & EA \\
\hline 18 & Construct good foundation base for mounting electrical machines & 4.83 & 132 & EA \\
\hline 19 & Ability to properly mount electrical machines & 4.69 & 1.08 & EA \\
\hline 20 & Ability to carryout various types of connections eg star-delta etc & 4.60 & 1.56 & EA \\
\hline 21 & Ability to install machines using appropriate cables & 4.61 & 1.25 & EA \\
\hline 22 & Ability to select appropriate circuits & 4.00 & 0.95 & HA \\
\hline 23 & Ability to carryout various machine tests & 438 & 1.00 & HA \\
\hline \multirow[t]{2}{*}{24} & Ability to observe safety measures provided by IEEE & $\begin{array}{l}3.29 \\
4.40\end{array}$ & $\begin{array}{l}1.55 \\
1.30\end{array}$ & $\begin{array}{l}\text { MAA } \\
\text { HA }\end{array}$ \\
\hline & $\begin{array}{l}\text { Cluster } 4 \text { : Maintenance of Electrical Equipment and Machines } \\
\text { Conducting different types of electrical equipment and machine }\end{array}$ & & & \\
\hline 25 & maintenance & 4.60 & 1.15 & HA \\
\hline 26 & Identification of grades of lubricants & 4.62 & 1.62 & EA \\
\hline \multirow[t]{2}{*}{27} & Identification correct tools/equipment for maintenance of machines & 329 & 1.55 & MLA \\
\hline & & 4.67 & 1.54 & EA \\
\hline \multicolumn{5}{|c|}{$\begin{array}{c}\text { Cluster 5: Repairs of Electrical Machines, Equipment and } \\
\text { Installation }\end{array}$} \\
\hline 28 & Identification of cause of electrical machine/equipment breakdown & 4.65 & 1.53 & EA \\
\hline 29 & Ability to interpret circuit diagrams of equipment/machines & 3.62 & 1.62 & HA \\
\hline 30 & Ability to select appropriate tools/equipment to repair faulty parts & 3.40 & 0.65 & MCA \\
\hline 31 & Ability to conduct visual inspection of machine parts & 4.62 & 122 & EA \\
\hline \multirow[t]{3}{*}{32} & Correct tests of electrical machine performance & 3.35 & 1.15 & MLA \\
\hline & & 3.85 & 1.02 & HA \\
\hline & Grand Mean & 3.24 & 1.02 & MA \\
\hline
\end{tabular}

$\overline{\mathrm{X}}=$ Mean rating of graduates of EDM, $\bar{\delta}=$ standard deviation, $\mathrm{N}=$ Number of graduates of ELV, $\mathrm{BA}=$ ENcellently/Acquired. HA = Highly Acquired, MA = Moderately Acquired, SA = Slightly Acquired, NA = Not Acquired

TABLE 1 showed the level of skills acquired in industrial installation by graduates of electrical installation and maintenance works (EIM) trade of technical colleges in North Eastern Nigeria. TABLE 1 revealed that industrial installation module has five task clusters namely: installation of MICC cables, installation of ducts and trunking, installation of AC and DC machines, maintenance of electrical equipment and machines, repairs of electrical machines, and equipment and installation. TABLE 1 further revealed that graduates of EIM in North Eastern Nigeria moderately acquired skills in installation if MICC cables with an overall cluster mean of 2.36 .

Mean ratings to items in cluster two: installation of ducts and trunking showed that the graduates of EIM slightly acquired skills in the tasks cluster with mean of 1.57. Mean ratings of skills in installation of AC and DC machines reveals that the graduates highly acquired skills in the task cluster with mean of 4.40 . Mean 
ratings to items in maintenance of electrical equipment and machines showed that the graduates excellently acquired skills in the entire tasks cluster with mean value of 4.67. Mean ratings of skills in repairs of electrical machines, equipment and installation, revealed that the graduates highly acquired skills in the tasks cluster with mean of 3.85. On the overall, the graduates moderately acquired skills in industrial installation with a grand mean of 3.24.

To answer research question two, mean, standard deviation and mean of means of the ratings of graduates and supervisors on the level of job performance of graduates in industrial installation module were calculated, and presented in TABLE 2.

Table 2: Mean Ratings of Graduates of EIM and Supervisors on Level of Job Performance of Graduates in Industrial Installation

\begin{tabular}{|c|c|c|c|c|c|c|c|}
\hline \multirow[t]{2}{*}{$\mathbf{S} / \mathbf{N}$} & \multirow[t]{2}{*}{ Domestic Installation Module (CEI 12) } & \multicolumn{2}{|c|}{$\mathbf{n}_{1}=313 \quad \mathbf{n}_{2}=82$} & \multicolumn{2}{|c|}{$N=395$} & \multirow[b]{2}{*}{$\bar{x}_{c}$} & \multirow[b]{2}{*}{ Remarlss } \\
\hline & & $\overline{\mathrm{X}}_{1}$ & $\delta_{1}$ & $\overline{\mathrm{X}}$ & $\delta_{2}$ & & \\
\hline & Clester 1: Installation of MICC Cables & & & & & & \\
\hline 1 & Ideatification of MIOC cables & 4.36 & 0.52 & 4.20 & 1.22 & 4.32 & $\mathrm{HP}$ \\
\hline 2 & Correct selection of tools materials wed in MOC cable inotallation & 4.53 & 0.52 & 4.07 & 1.07 & 4.43 & $\mathrm{HP}$ \\
\hline 3 & Carry oot MIOC cable inutallasions obuerving relevant regalations & 393 & 0.89 & 3.58 & 1.07 & 3.85 & HP \\
\hline 4 & Termination of MUCC cables emphasizing IFEF regalations & 1.42 & 1.06 & 1.17 & 1.24 & 1.36 & $\mathrm{NP}$ \\
\hline \multirow[t]{2}{*}{5} & Contocting various tests on completed MIOC installations applying & & & & & & \\
\hline & gatolore regalasions & 3.55 & 1.25 & 3.25 & 1.21 & 3.48 & MP \\
\hline 6 & Abdity to carry-ost simple woface wiring for intustral installations & 3.02 & 1.31 & 295 & 1.09 & 3.00 & $\mathrm{MP}$ \\
\hline 7 & Ability to carry ost simple cootsit wiring for intustrial installations & 1.14 & 1.04 & 1.02 & 1.20 & 1.11 & $\mathrm{NP}$ \\
\hline \multirow[t]{3}{*}{8} & Installasion of MOCC cables applying oecesary safety mearxes & 1.05 & 1.17 & 1.01 & 1.03 & 1.04 & $\mathrm{NP}$ \\
\hline & 01 & & & & & 2.85 & MP \\
\hline & Cluster 2: Installation of Docts and Frunking & & & & & & \\
\hline 9 & Ability to differentiate types of docts truaking & 1.25 & 0.72 & 105 & 1.04 & 1.20 & $\mathrm{NP}$ \\
\hline 10 & Abiling to join differeat lengthe of dxets truaking & 1.36 & 1.25 & 1.26 & 1.11 & 1.33 & $\mathrm{NP}$ \\
\hline 11 & Accurate marking oot mbea evting boles & 122 & 0.85 & 1.12 & 0.93 & 1.19 & $\mathrm{NP}$ \\
\hline 12 & Making bead set ibape fule & 1.30 & 0.71 & 1.07 & 1.02 & 1.23 & $\mathrm{NP}$ \\
\hline 13 & Ability to fabricats accewories used for dxcts truaking & 1.17 & 0.83 & 1.10 & 0.96 & 1.25 & NP \\
\hline 14 & Ability to provide earth coetimvity in all types of docts truaking & 1.42 & 0.92 & 1.07 & 0.57 & 1.15 & $\mathrm{NP}$ \\
\hline \multirow[t]{3}{*}{15} & Obenervation of safety mearres as provided by IFEF regalasions & 3.33 & 0.45 & 3.02 & 1.05 & 1.34 & $\mathrm{NP}$ \\
\hline & & & & & & 1.53 & LP \\
\hline & Chuter 3: Installation of AC and DC Machines & & & & & & \\
\hline 16 & Identification of variogs types of electrical machioes & 3.60 & 1.34 & 3.75 & 0.58 & 3.63 & HP \\
\hline 17 & Ability to ideatify various types of machine eaclocuces & 3.26 & 1.17 & 298 & 0.94 & 3.20 & $\mathrm{MP}$ \\
\hline 18 & Construet good forodation base for moveting electrical machioes & 3.71 & 1.19 & 3.53 & 0.94 & 3.67 & HP \\
\hline 19 & Ability to properly movat electrical machioss & 3.68 & 1.14 & 3.49 & 0.97 & 3.64 & HP \\
\hline 20 & Abiling to carry out various types of conoections eg star-dela ete & 252 & 1.11 & 220 & 1.31 & 245 & LP \\
\hline 21 & Ability to install machioes wsing appropriate cables & 2.66 & 1.36 & 2.61 & 1.41 & 2.64 & $M$ \\
\hline 22 & Ability to select appropriate circuits & 2.17 & 1.10 & 200 & 0.77 & 2.13 & LP \\
\hline 23 & Abling to carry ost various machine tests & 229 & 1.07 & 208 & 1.06 & 224 & LP \\
\hline \multirow[t]{3}{*}{24} & Abiling to obuerve safety measuces provided by IFEF & 3.52 & 1.05 & 298 & 0.83 & 3.40 & $\mathrm{MP}$ \\
\hline & & & & & & 3.00 & MP \\
\hline & Cluster 4: Maintenance of Electrical Equipment and Machines & & & & & & \\
\hline \multirow[t]{2}{*}{25} & Cootweting differeat types of electrisal equipment and machios & & & & & & \\
\hline & mainepeps. & 3.02 & 1.42 & 2.58 & 0.84 & 299 & $M P$ \\
\hline 26 & Identification of grades of hbbricants & 3.59 & 0.59 & 3.38 & 0.76 & 3.78 & HP \\
\hline \multirow[t]{2}{*}{27} & Ideatification correct vols equipmeat for mainteasace of machioes & 3.52 & 1.02 & 3.32 & 1.02 & 3.47 & $M P$ \\
\hline & & & & & & 3.41 & MP \\
\hline \multicolumn{8}{|c|}{ Cluster 5: Repairs of Electrical Machines, Equipment and } \\
\hline \multicolumn{8}{|c|}{ Installation } \\
\hline 28 & Identification of cavse of electrical machioe equipment brealadona & 3.58 & 1.21 & 3.69 & 0.95 & 3.54 & HP \\
\hline 29 & Abiling to intergert circvit diagrams of equipment machines & 3.71 & 1.00 & 3.62 & 1.01 & 3.69 & $\mathrm{HP}$ \\
\hline 30 & Ability to select appropriate tools equipmeat to repair fasity parts & 3.12 & 0.81 & 3.00 & 1.08 & 3.09 & MA \\
\hline 31 & Ability to contret virsal inspection of machios parts & 4.17 & 1.05 & 4.05 & 0.87 & 4.14 & HP \\
\hline \multirow[t]{3}{*}{32} & Contjet tests of electrical machine performace & 3.58 & 0.98 & 3.45 & 1.06 & 3.55 & $\mathrm{HP}$ \\
\hline & & & & & & 3.65 & HA \\
\hline & Grand Mesn & 2.82 & 1.12 & 2.63 & 1.10 & 2.78 & MA \\
\hline
\end{tabular}

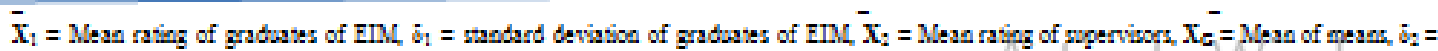

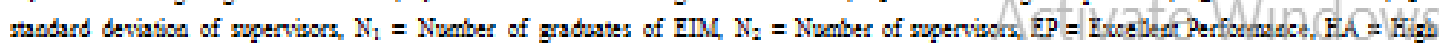
Performance, MA = Moderate Performance, LP = Lor: Performace, $P$ P = Poor Performance 
TABLE 2 showed the level of job performance of graduates of electrical installation and maintenance works (EIM) trade of technical colleges in industrial installation in North Eastern Nigeria. TABLE 2 also revealed that industrial installation has five task clusters namely, installation of MICC cables, installation of ducts and trunking, installation of AC and DC machines, maintenance of electrical equipment and machines and repairs of electrical machines, equipment and installation. TABLE 2 showed that the EIM graduates exhibited high level of job performance in one tasks cluster only: repairs of electrical machines, equipment and installation with a pulled mean value of 3.66 .

Mean ratings of job performance in tasks cluster 2: installation of ducks and trunking showed that the graduates exhibited low level of job performance, having mean of 1.53. The remaining three task clusters showed that the graduates exhibited moderate level of job performance with means ranging from 2.86- 3.41.

To test hypothesis one, grand means and standard deviations of the ratings of graduates and supervisors on the job performance of graduates in industrial installation module were calculated and used to determine $\mathrm{z}$ value as shown in TABLE 3 .

Table 3: z-Test Analysis of the Ratings of Graduates and Supervisors on Level of Job Performance of Graduates in Industrial Installation

\begin{tabular}{|c|c|c|c|c|c|c|c|}
\hline Respondents & $\bar{X}$ & $\delta$ & $\mathrm{N}$ & SE & $\mathrm{Z}_{\mathrm{cal}}$ & $\mathrm{z}_{\text {crit }}$ & Remarks \\
\hline EIMWG & 2.82 & 1.12 & 313 & \multirow{2}{*}{$\begin{array}{l}0.12 \\
0.19\end{array}$} & \multirow[b]{2}{*}{1.46} & \multirow[b]{2}{*}{1.96} & \multirow[b]{2}{*}{ NS } \\
\hline EIMWS & 2.63 & 1.10 & 82 & & & & \\
\hline
\end{tabular}

TABLE 3: shows that the $\mathrm{z}_{\text {cal }}$ (1.46) was less than the table value $\mathrm{z}_{\mathrm{cri}}(1.96)$ hence the null hypothesis $\mathrm{H} 0_{2}$ was accepted indicating that there was no significant difference between the mean ratings of graduates of electrical installation and maintenance works trade of technical colleges and their supervisors on the job performance of graduates in domestic installation.

\section{FINDINGS OF THE STUDY}

Based on the results obtained from the analyzed data, the following findings were deduced about level of technical skills acquired and job performance of graduates of electrical installation and maintenance works trade of technical colleges in North Eastern Nigeria. The findings revealed that the EIM graduates:

1. Moderately acquired skills in industrial installation; the graduates therefore,

i. Moderately acquired skills in installation of MICC cables cluster

ii. Slightly acquired skills in installation of ducts and trunking cluster

iii. Highly acquired skills in installation of AC and DC machines cluster

iv. Excellently acquired skills in maintenance of electrical equipment and machines cluster

v. Highly acquired skills in repairs of electrical machines, equipment and installation cluster

2. Exhibited moderate level of job performance in industrial installation; the graduates exhibited

i. Moderate level of job performance in installation of MICC cables cluster

ii. Low level of job performance in installation of ducts and trunking cluster

iii. Moderate level of job performance in installation of AC and DC machines cluster

iv. Moderate level of job performance in maintenance of electrical equipment and machines cluster

v. High level of job performance in repairs of electrical machines, equipment and installation cluster

3. The study found out that there was no significant difference in the mean ratings of graduates and supervisors on the level of job performance of graduates in industrial installation

\section{DISCUSSION}

Findings of the study have been discussed based on the pattern of the research questions and hypotheses.

Findings in industrial installation showed that EIM graduates moderately acquired skills in the module. The moderate acquisition of skills in this module is due largely to the short fall in skills from teachers who tend to skip or lay little emphasis on some vital task cluster such as installation of ducts and trunking and installation of MICC cables where the graduates showed little acquisition of skills with mean values of 1.57 and 2.36 respectively. This situation can be seen in the findings of [32] who generalized that technical college graduates lack basic skills in industrial installation and do not perform to the satisfaction of their employers due to mismatch of skills acquired while in schools. Another important fact is that equipment and measuring instruments used in training in industrial installation were not available in most of the technical colleges where these EIM graduates were trained as rightly found out by [33]. His study found out that ninety percent of the 173 tools, equipment and measuring tools used in the existing and emerging fields in industrial installation were not included in the technical college recommended tools and equipment specification list. Similarly, [34] also found in his study that technical equipment and infrastructures were found to be inadequate. [35] also reported that 
when students go on industrial experience scheme, they are not exposed to tasks in industrial installation. This position is also pertinent and concurred with the findings of [36] on the efficacy of technical programmes which revealed that technical college graduates lack the requisite practical skills for the world of work.

Findings on the level of job performance of EIM graduates in industrial installation showed that the graduates exhibit moderate job performance in the module. This finding is due to the physical nature of the task clusters within the module and the fact that graduates are found to acquire skills in working drawings and observation of safety rules and regulations. The graduates showed low performance in utilization of many new and emerging tools and equipment in industrial installation which totally agreed with the findings [33]. His study found out that ninety percent of the 173 tools, equipment and measuring tools used in the existing and emerging fields in industrial installation were not included in the technical college recommended tools and equipment specification list. Some tasks operations in this module are similar to those in domestic installation thereby contributed to the findings in this module.

Findings on hypothesis two showed that the EIMW graduates and their supervisors agree on the level of job performance of the graduates in industrial installation. This finding was evident due to the fact that the calculated $\mathrm{Z}$ value (1.46) of the two respondents is lower than the tabulated $\mathrm{Z}$ value (1.96). Even though finding showed that EIM graduates felt they can perform reasonably in this module ( mean $=2.82$, standard deviation $=$ 1.12), their supervisors felt not far otherwise (mean $=2.63$, standard deviation $=1.10$ ) an indication that the differences were not significant. Yet, the finding showed a likely hood of skip by teachers of some vital topics in this module and inadequate technical equipment and infrastructures for teaching tasks such as installation of ducts and trunking, demonstration of the use of bell set and application of various new industrial equipment among others were their mean performances were found to be low. The findings in this module agreed with that of [34] and [33] which showed that technical equipment and infrastructures in technical colleges in Nigeria were found to be inadequate especially for the teaching of emerging industrial installations.

\section{CONCLUSION}

Based on the results of this study, it can be concluded that graduates of electrical installation and maintenance works trade of technical colleges in North Eastern Nigeria moderately acquired skills in two task clusters, excellently acquired skills in one task cluster, highly acquired skills in one task cluster and slightly acquired skills in one task cluster in industrial installation module. Graduates of electrical installation and maintenance works trade of technical colleges in North Eastern Nigeria exhibited moderate level of job performance in four task clusters and exhibited slight level job performance in one task cluster and low level of job performance in one task cluster in industrial installation module. It was also concluded that the graduates of electrical installation and maintenance works trade of technical colleges in North Eastern Nigeria moderately acquired skills in industrial installation module of the trade and have moderate level of job performance in industrial installation module.

\section{RECOMMENDATIONS}

Based on the conclusions presented, the following actions appear warranted with regard to the issues addressed by the research questions and hypotheses in this study:

1. Emphasis should be given on industrial installation module because of its wide application to the graduates of electrical installation and maintenance works trade

2. On the job training should be provided by work place based supervisors to remedy the very low skills acquired by EIM gradates in some task clusters in industrial installation module

3. Work place based supervisors should organize in- house training on areas where EIM graduates lacks skills e.ginstallation of ducks and trunkings and new and emerging installation of MICC cable technologies

4. EIM graduates need improvement in their job performance in all the tasks clusters in industrial installation module where they exhibited moderate level of job performance

\section{REFERENCES}

[1] A.Dyankov, Current issues and trends in technical and vocational education.Proc. $21^{\text {st }}$ UNESCO Conf. on Technical and Vocational Education.Paris, France, 1996, 40 -50.

[2] O.H.Idriss, and E.Y. Garba, Vocational technical and entrepreneurial education.for schools and businessmen. (Lagos: T. Richard, 2007).

[3] G. K. G.Singh,and S. K. G. Singh, Malaysian graduates' employability skills.Unitar e-Journal.4(1), 2008, 14-44

[4] F. J., Krieg, P.Brown,andJ.Ballard, Transition: school to work.(Bethesda, MD: TheNational Association of School Psychologists, 2005).

[5] H. A.Spille, Postsecondary curricula must emphasize generic employability skills, Adult Learning, 5 (5), $2004,17-19$.

[6] A. P. Carnevale, L. J.Gainer, andA. S.Meltzer, Workplace basics: the skills employers need (Washington DC, ERICS, 2009)

[7] C. M.,Ile, M. W.Asoegwu, and G. C.Chukwugbo, Essentials of vocational education and technical education forbeginners.(Awka: Marpat Educational Research and Publishers, 2005).

[8] L.Koffel, Teaching workplace skills: creative ways to teach students the skills employers want.(Houston, TX: Gulf, 2004). 
[9] W. Grubb, Betwixt and between: education, skills, and employment in Sub- Baccalaureate labour markets. (Berkeley, CA: ERIC, ED 353 412, 2009).

[10] P. C.Okwelle, Development and validation of instrument for assessing practical skills in building electrical system in Nigeria. Nigeria Technical Trends in Engineering and Applied Sciences.3(3).2011, 25-31.

[11] G. D. Cheek, The secondary vocational program, in A. J. Pautler, (Ed.), Vocational education in the 1990's: major issues, 2 (Ann Arbor, MI: Prakken, 1993) 45-70

[12] F. Osuji, Forward to the national technical certificate and advanced national technical certificate curriculum and module specification.(Kaduna, Nigeria, NBTE, 2003).

[13] C. G.Nwokomah, Strategy for attaining functional vocational and technical education in the $21^{\text {st }}$ century in Nigeria. Journal of Education in Developing Areas. 1(14), 2005, 53-61.

[14] J. P. Campbell, Modellingtheperformance prediction problem in industrial and organizational psychology. In M. D. Dunnette\& L. M. Hough (Ed.), Handbook of industrial/organizational psychology, 1 (Palo Alto, CA: Consulting Psychologists, 1990) 687-732.

[15] J.,VanScotter, S. J., Motowidlo, and T. C. Cross, Effects of task performance and contextual performance on systemic rewards. Journal of Applied Psychology,85 (1), 2000, 526-535.

[16] I. Sule, How relevant are our Nigerian schools? In J. A. Akintola (Ed.), Issues and problems of technical education at the secondary school level in Nigeria.1 (Zaria, Nigeria, National Education Research Council, 2009) 55-60.

[17] E.W.Osbon, Psychomotor skills performance level. ILO Journal of EducationRreosurses, 2(12), 2006, 22-23.

[18] T. U. Aminu, Development and validation of an instrument for assessing performance of students on welding and fabrication trade at technical college level, doctoral diss., ModibboAdamaUniversityof Technology, Yola, Nigeria, 2015.

[19] Federal Republic of Nigeria, Assessment and training package for domestic electrician.(Abuja, Federal Ministry of Education, 2012).

[20] B. N.Atsumbe, Basic academic, practical and affective skills to be emphasized in the technical college curriculum. Journal of Nigerian Association of Teachers of Technology, 1(4), 2002.119-126.

[21] M.M. Adamu, Employability skill acquisition of career and technical education students(New York, Guildford Press, 2009)

[22] J. Anamuah-Mensah, and P. Towse, Bringing industry into the science classroom - problems, concerns and prospects associated with a paradigm shift,Proc. $7^{\text {th }}$ IOSTE Conf. on Science and Technology Education in a Demanding Society Enschede, Netherlands, 1995.

[23] R.Stevenson, The huddersfield experiment. Chemistry in Britain, 31(11),1995, $845-847$.

[24] J.A. Muskin, Becoming an independent entrepreneur in the formal sector of northern Cote d'Ivoire: what role can technical schooling play? International Journal of Educational Development, 2 (17), 1997, 265 - 283.

[25] G. Tabron, and J. Yang, The interaction between technical and vocational education and training (TVET) and economic development in advanced countries. International Journal of Educational Development, 12(17), 1997, 323 - 334.

[26] V.O. Uwaifu, Industrializing the Nigerian society through creative skill acquisition vocational and technical education programme. International NGO Journal, 4(4),2009.142-145.

[27] A. R Akilu,andE.Y.Garba, Developing appropriate entrepreneurial skills for personal economic empowerment and national development. International Journal of Educational Studies, 3(6), 2011, 25-28.

[28] UNDP,Skills training manual in electrical installation and maintenance work:.a state outcome committee, (Yola, Nigeria, UNDP, 2009).

[29] A.A.Sambo, Research methods in education,(Lagos, Sterling - Horden, 2005).

[30] K. Mohammed, Historical background. In A. A. Adebayo \& A. L. Tukur.Adamawa state in maps.(Yola: Paraclate, 1999) 1-3.

[31] National Board for Technical Education (NBTE), National technical certificate and advanced National technical certificate curriculum and course specifications in electrical installation. (Kaduna, Nigeria, NBTE, 2007).

[32] M. B. Aliyu, The need for improving the evaluation procedures of practical projects in technology education: A necessity for sustainable national vision. Proc. $12^{\text {th }}$ NAAT Conf. on Technology Education and the Realization of the Vision 2010, Minna, Nigeria, 2009.18-22.

[33] U. A.Ukoha, Technological developments in electricity/electronics with implications for training in the practical component of Nigeria certificate in education (technical) curriculum, doctoral diss., University of Nigeria, Nsukka, Nigeria, 2002.

[34] O.Okonkwo, Assessment of the implementation of technical colleges' modular curriculum in selected states in Nigeria, doctoral diss., University of Nigeria, Nsukka, Nigeria, 1997.

[35] H. U. Elobuike, Relevance of technical college electrical/electronics and mechanical/ automobile programmes to the needs of industries in Anambra, Ebonyi and Enugu states, doctoral diss., University of Nigeria, Nsukka, 1999.

[36] F.H.,Akplu, and J.Y.Amankrah, Restructuring the technical and vocational education training (TVET) curricula to meet industry needs. Asia-Pacific Journal of Cooperative Education, 11(1),2010, 13-25. 